\title{
PENGARUH EARNING PER SHARE, DEBT TO EQUITY RATIO, RETURN ON EQUITY DAN CURRENT RATIO TERHADAP PRICE TO BOOK VALUE PERUSAHAAN SUB SEKTOR ADVERTISING PRINTING MEDIA YANG TERDAFTAR DI BURSA EFEK INDONESIA TAHUN 2014-2017
}

\author{
Mutiara Via Maudy \\ blaekpearls@gmail.com \\ Universitas Ahmad Dahlan \\ Deny Ismanto \\ denoxis@yahoo.com \\ Universitas Ahmad Dahlan
}

\begin{abstract}
ABSTRAK
This study aims to examine the effect of Earning Per Share, Debt To Equity Ratio, Return On Equity and Current Ratio to Price to Book Value on advertising printing media companies listed on the Indonesia Stock Exchange for the period 2014-2017. This research is descriptive quantitative research. The research population is all advertising printing media companies listed on the Indonesia Stock Exchange for the period 2014-2017 with a total of 15 companies. The sample selection was determined by purposive sampling technique with the criteria of the stock being sampled were the companies that published their financial statements during the consecutive research year, so that samples are 12 companies were obtained. This study uses a statistical panel data regression analysis tool. The results of the study using Earning Per Share, Debt To Equity Ratio, Return On Equity and Current Ratio to Price to Book Value have results, the Debt To Equity Ratio variable affects the dependent variable Price to Book Value, while the other independent variables have no effect, that is; Earning Per Share, Return On Equity and Current Ratio. With the value of R Squared of $66.5 \%$ which explains the large influence on Price to Book Value.
\end{abstract}

Keywords: Earning Per Share, Debt To Equity Ratio, Return On Equity, Current Ratio, Price to Book Value.

\section{PENDAHULUAN}

Periklanan merupakan suatu bentuk komunikasi dengan tujuan mengajak orang yang melihat, membaca atau mendengarnya untuk melakukan sesuatu. Promosi yang dilakukan mencakup nama produk atau layanan serta bagaimana produ dan layanan tersebut dapat memberikan manfaat bagi calon pembeli. Periklanan terdapat pada dunia pertelevisian, maupun media cetak, sejak awal tahun 1990an, seiring dengan berkembangnya teknologi kini periklanan memulai media baru, yakni internet.
Berdasarkan laporan Advertising Expenditure Forecasts oleh Zenith, sebuah agensi yang berkecimpung dalam ranah Return of Investment, dikatakan bahwa Malaysia, Indonesia, Filipina, dan Tiongkok diekspektasi akan memiliki peningkatan biaya rata-rata sebesar 7,4\% tiap tahunnya hingga 2020 untuk pengembangan bidang periklanan. Negara-negara tersebut merupakan sebagian dari kontributor advertising global terbesar dari kelompok rising market. Kelompok inilah yang nantinya dilansir akan berkontribusi terhadap $40 \%$ perkembangan biaya advertising global 
dalam tiga tahun ke depan. Dari angka tersebut, periklanan via internet diprediksi akan mengalami peningkatan sebesar $10 \%-20 \%$ tiap tahunnya, sehingga periklanan menggunakan media konvensional seperti televisi akan semakin tergeser.

Indonesia sebagai salah satu negara berkembang dituntut untuk senantiasa meningkatkan pertumbuhan ekonomi masyarakatnya melalui pembinaan pilarpilar ekonomi yang dianggap mampu menopang dan meningkatkan kesejahteraan masyarakat secara adil dan merata. Perusahaan menurut (Salvatore, 2005) adalah suatu organisasi yang mengkombinasikan berbagai sumber daya dengan tujuan untuk memproduksi barang dan atau jasa untuk dijual.

Menurut Indriyo (1997) dana merupakan kekayaan atau aktiva yang diperlukan untuk melakukan kegiatan sehari-hari dan selalu berputar. Sedangkan menurut Riyanto (2004) dana dikemukakan dengan adanya tiga konsep, yaitu: Konsep kuantitatif; berdsasarkan pada kuantitas dari dana yang tertanam dalam keseuruhan unsur-unsur aktiva lancar dimana dana tertanam di dalamnya akan dapat bebas lagi dalam waktu yang pendek, konsep kualitatif, sebagian dari aktiva lancar yang benar-benar dapat di gunakan untuk membiayai operasi perusahaan tanpa mengganggu likuiditasnya, dan konsep fungsional, berdasarkan fungsi dari dana dalam menghasilkan pendapatan sehingga setiap dana yang dikerjakan dalam perusahaan dimaksudkan untuk menghasilkan laba.

Fluktuasi nilai PBV perusahaan manufaktur dari tahun ke tahun terjadi karena ada faktor-faktor yang mempengaruhi PBV. Salah satu variabel yang mempengaruhi PBV yaitu struktur modal perusahaan. Pengertian struktur modal menurut Riyanto (2001) adalah perimbangan atau perbandingan antara jumlah hutang jangka panjang dengan modal sendiri. Oleh karena itu, struktur modal di-proxy dengan Debt To Equity Ratio (DER), yang merupakan perbandingan antara total hutang terhadap modal sendiri.

Indikator lain yang menjadi salah satu penentu keputusan investasi yang sering digunakan oleh investor adalah Earning Per Share (EPS). Earning Per Share adalah kemampuan setiap lembar saham dalam menciptakan laba dalam satu periode pelaporan keuangan. Besarnya EPS menunjukkan besarnya laba bersih perusahaan yang siap dibagikan untuk para pemegang saham dari jumlah saham yang beredar (Tandelilin, 2001). Semakin besar nilai EPS, maka semakin besar pula laba bersih yang disediakan perusahaan untuk para pemegang saham. Dengan demikian, minat investor akan meningkat dan berpengaruh pada naiknya harga saham sehingga nilai perusahaan juga ikut meningkat.

Return On Equity (ROE) adalah faktor lain yang perlu diperhitungkan oleh calon investor. Return On Equity (ROE) adalah rasio pengembalian atas total ekuitas yang dimiliki perusahaan. ROE adalah rasio profitabilitas yang paling mendasar (Brigham, 2004). Profitabilitas berpengaruh pada kelangsungan hidup perusahaan untuk jangka panjang, dalam arti lain adalah prospek di masa depan. Adanya pertumbuhan nilai ROE membuat perusahaan mampu meningkatkan potensi laba ke depan sehingga menarik perhatian investor untuk menanamkan modal pada perusahaan. Meningkatnya ketertarikan investor akan meningkatkan permintaan terhadap saham perusahaan sehingga harga saham menjadi mahal dan berpengaruh pada nilai perusahaan yang diukur dengan PBV. 
Current Ratio merupakan salah satu rasio likuiditas. Rasio lancar atau Current Ratio merupakan rasio untuk mengukur kemampuan perusahaandalam membayar kewajiban jangka pendek atau utang yang segera jatuh tempo pada saat ditagih secara keseluruhan (Kasmir 2015).

Dalam penelitian ini obyek penelitian yang digunakan adalah perusahaan subsektor pertambangan logam dan mineral yang terdaftar di Bursa Efek Indonesia. Terdapat 10 perusahaan yang terdapat di subsektor ini. Tujuan dari penelitian ini diantaranya: 1) untuk mengetahui pengaruh Return On Equity (ROE) terhadap Price Book Value (PBV) pada perusahaan sub sektor advertising printing media yang terdaftar BEI tahun 2014-2017, 2) untuk mengetahui pengaruh Debt To Equity Ratio (DER) terhadap Price Book Value (PBV) pada perusahaan sub sektor advertising printing media yang terdaftar BEI tahun 2014-2017, 3) untuk mengetahui pengaruh Current Ratio terhadap Price Book Value (PBV) pada perusahaan sub sektor advertising printing media yang terdaftar BEI tahun 2014-2017 dan 4) untuk mengetahui pengaruh Earning Per Share (EPS) terhadap Price Book Value (PBV) pada perusahaan sub sektor advertising printing media yang terdaftar BEI tahun 2014-2017.

\section{REVIEW LITERATUR DAN HIPOTESIS}

\section{Landasan Teori}

\section{Pasar Modal}

Undang-Undang Pasar Modal No. 8 tahun 1995 tentang Pasar Modal mendefinisikan pasar modal sebagai kegiatan yang bersangkutan dengan penawaran umum dan perdagangan efek, perusahaan publik yang berkaitan dengan efek yang diterbitkannya, serta lembaga dan profesi yang berkaitan dengan efek.
2. Saham

Menurut Darmadji (2006) saham adalah sebagai tanda penyerta atau pemilikan seseorang.

3. Rasio Keuangan

Rasio keuangan atau financial ratio merupakan alat analisis keuangan perusahaan untuk menilai kinerja suatu perusahaan berdsasarkan perbandingan data keuangan yang terdapat pada pos laporan keuangan (neraca, laporan laba rugi, laporan aliran kas). Rasio menggambarkan suatu hubungan atau perimbangan (mathematical relationship) antara suatu jumlah tertentu dengan jumlah yang lain.

\section{Return On Equity (ROE)}

Menurut Jogiyanto (2010), Return On Equity (ROE) adalah salah satu rasio profitabilitas yang mengukur kemampuan perusahaan untuk menghasilkan laba dengan berdasarkan modal saham tertentu.

\section{Debt To Equity Ratio (DER)}

Debt To Equity Ratio (DER) merupakan rasio yang digunakan untuk mengukur sejauh mana besarnya hutang dapat ditutupi oleh modal sendiri (Tjiptono, 2006).

\section{Current Ratio (CR)}

Gambaran seberapa banyak aktiva lancar tersedia untuk menutupi kewajiban jangka pendek yang segera jatuh tempo (Kasmir, 2015).

\section{Earning Per Share (EPS)}

Laba per lembar saham atau Earning Per Share (EPS) menunjukkan perbandingan antara besarnya laba bersih perusahaan yang siap dibagikan kepada para pemegang saham perusahaan dengan jumlah saham yang beredar (Tandelilin, 2001). 
8. Price Book Value (PBV)

Price to Book Value (PBV) menurut Husnan (2006) merupakan perbandingan antara harga pasar dan nilai buku saham.

\section{Penelitian Terdahulu}

Prasetya (2014) dalam penelitian mereka yang berjudul "Pengaruh Struktur Modal, Ukuran Perusahaan dan Risiko Perusahaan terhadap Nilai Perusahaan Otomotif yang terdaftar di BEI" pada periode 2009 - 2012 menunjukkan bahwa struktur modal (DER), ukuran perusahaan (total aset), risiko perusahaan (beta) secara simultan berpengaruh terhadap nilai perusahaan (PBV). Secara parsial, struktur modal berpengaruh positif tetapi tidak signifikan terhadap nilai perusahaan. Ukuran perusahaan berpengaruh positif dan signifikan terhadap nilai perusahaan.

Hasania (2016) dalam penelitian mereka yang berjudul "Current Ratio, Ukuran Perusahaan, Struktur Modal dan ROE terhadap Nilai Perusahaan Farmasi yang terdaftar di Bursa Efek Indonesia periode 2011-2014" menunjukkan bahwa Current Ratio, Ukuran Perusahaan, Struktur Modal dan ROE secara simultan memiliki pengaruh yang signifikan terhadap Nilai Perusahaan pada perusahaan Farmasi di Bursa Efek Indonesia, sedangkan secara parsial Current Ratio, Struktur Modal dan ROE berpengaruh signifikan terhadap Nilai Perusahaan. Sementara Ukuran Perusahaan tidak berpengaruh signifikan terhadap Nilai Perusahaan.

\section{Hipotesis}

H1: Earning Per Share (EPS) berpengaruh positif signifikan terhadap Price to Book Value (PBV).
H2: Debt To Equity Ratio (DER) berpengaruh negatif signifikan terhadap Price to Book Value (PBV).

H3: Return On Equity (ROE) berpengaruh positif signifikan terhadap Price to Book Value (PBV).

H4: Current Ratio (CR) berpengaruh positif signifikan terhadap Price to Book Value (PBV).

\section{METODE PENELITIAN}

\section{Populasi dan Sampel}

Populasi yang digunakan dalam penelitian ini adalah perusahaan sub sektor advertising printing media yang terdaftar di Bursa Efek Indonesia berjumlah 15 perusahaan periode tahun 2014-2017. Sampel yang digunakan dalam penelitian ini sebanyak 12 perusahaan. Pengambilan sampel dalam penelitian ini dilakukan dengan menggunakan teknik purposive sampling, yaitu pengambilan sampel berdasarkan kriteria tertentu:

1. Terdaftar sebagai perusahaan sub sektor advertising printing media aktif yang ada di Bursa Efek Indonesia (BEI) pada tahun 2014-2017.

2. Perusahaan yang mempublikasikan laporan tahunannya di BEI.

3. Perusahaan sub sektor advertising printing media yang menerbitkan PBV, EPS, DER, ROE dan CR tiap periode berturut-turut mulai tahun 2014-2017.

\section{Definisi Operasional}

1. Variabel Independen a. Earning Per Share

Laba per lembar saham atau Earning Per Share (EPS) menunjukkan perbandingan antara besarnya laba bersih perusahaan yang siap dibagikan kepada para pemegang saham perusahaan dengan 
jumlah saham yang beredar (Tandelilin, 2001).

\section{b. Debt To Equity Ratio}

Debt To Equity Ratio (DER) merupakan rasio yang digunakan untuk mengukur sejauh mana besarnya hutang dapat ditutupi oleh modal sendiri (Tjiptono, 2006).

c. Return On Equity

Menurut Jogiyanto (2010), Return On Equity (ROE) adalah salah satu rasio profitabilitas yang mengukur kemampuan perusahaan untuk menghasilkan laba dengan berdasarkan modal saham tertentu.

\section{d. Current Ratio}

Gambaran seberapa banyak
aktiva lancar tersedia untuk menutupi kewajiban jangka pendek yang segera jatuh tempo (Kasmir, 2015).

2. Variabel Dependen

Variabel terikat yang terdapat dalam penelitian ini adalah nilai perusahaan. Nilai perusahaan merupakan harga yang bersedia dibayar oleh calon pembeli apabila perusahaan tersebut dijual (Husnan, 2000). Price to Book Value (PBV) digunakan sebagai proksi dari nilai perusahaan karena keberadaannya sangat penting bagi investor untuk menentukan strategi investasi di pasar modal.

\section{Teknik Analisis Data}

1. Statistik Deskriptif

Menurut Sugiyono

statistik deskriptif adalah statistik yang digunakan untuk menganalisa data dengan cara mendeskripsikan atau menggambarkan data yang telah terkumpul sebagaimana adanya tanpa bermaksud membuat kesimpulan yang berlaku untuk umum.

\section{Asumsi Klasik}

a. Normalitas

Uji normalitas bertujuan untuk menguji apakah dalam model regresi, variabel terikat dan variabel bebas keduanya memiliki distribusi data normal atau tidak. Pengujian ini juga ditujukan untuk mendeteksi apakah faktor pengganggu berdistribusi secara bebas. Normalitas yang digunakan dalam penelitian ini menggunakan analisis uji Jarque Bera dengan melihat nilai prob. J-B lebih besar dari $5 \%$ atau alpha (prob. J-B > 0,05).

b. Autokorelasi

Uji autokorelasi bertujuan untuk menguji apakah dalam suatu model regresi linier terdapat korelasi antara kesalahan penggangu pada periode $\mathrm{t}$ dengan kesalahan pada periode $\mathrm{t}-1$ (sebelumnya). Jika terjadi korelasi, maka dinamakan ada problem autokorelasi. Autokorelasi muncul karena observasi yang berurutan sepanjang waktu berkaitan satu sama lain. Masalah ini timbul karena residual (kesalahan pengganggu) tidak bebas dari observasi satu ke observasi lainnya. Hal ini sering ditemukan pada data runtut waktu atau time series karena gangguan pada individu atau kelompok yang sama pada periode berikutnya.

Pengambilan keputusan dapat dilakukan dengan patokan sebagai berikut:

Prob chi square > 0.05 maka tidak ada autokorelasi

Prob chi square $<0.05$ maka terjadi autokorelasi 
c. Heteroskedastisitas

Uji heteroskedastisitas ini bertujuan untuk menguji apakah dalam model regresi terjadi ketidaksamaan varians dari residual satu pengamatan ke pengamatan lain. Jika varians dari satu pengamatan ke pengamatan yang lain tetap, maka disebut homoskedositas atau tidak terjadi heteroskedastisitas. Dan jika varians berbeda maka disebut heteroskedastisitas. Model regresi yang baik adalah yang homoskedastisitas atau tidak terjadi heteroskedasitas (Ghozali, 2006).

Pengambilan keputusan dalam

uji White dengan menggunakan program Eviews adalah:

Prob chi-square (p-value) $>0.05 \rightarrow$ tidak terjadi heteroskedastisitas

Prob chi-square (p-value) $<0.05 \rightarrow$ terjadi heteroskedastisitas

d. Multikolinieritas

Multikolinieritas adalah adanya suatu hubungan linier yang sempurna antara beberapa atau semua variabel independen. Uji multikolinieritas bertujuan untuk menguji apakah model regresi ditemukan adanya korelasi antar variabel bebas (independen). Model regresi yang baik seharusnya tidak terjadi korelasi diantara variabel bebas (Ghozali, 2006). Cara pengujian multikolinieritas pada penelitian adalah dengan nilai korelasi antar variabel independen dengan pengambilan keputusannya adalah bila nilai korelasi antar variabel independen $>0.85$ maka terdapat multikolinieritas (Widarjono, 2013).
3. Analisis Regresi Data Panel

Langkah awal dalam penentuan model adalah dengan meregresikan data dengan fixed effect, kemudian dilakukan dengan uji Chow dengan cara membandingkan nilai prob. Chi square dengan 0,05. Model common effect akan digunakan jika nilai prob. Chi square $>0,05$ dan sebaliknya jika nilai prob. Chi square $<0,05$ maka fixed effect yang dipilih.

Langkah selanjutnya jika model yang digunakan adalah common effect maka penentuan model berhenti disini, dengan kata lain model yang lebih tepat digunakan adalah model common effect. Namun jika uji Chow menunjukkan bahwa fixed effect yang dipilih, maka akan dilanjutkan pengujian yang kedua (uji Hausman) yaitu dengan membandingkannya dengan model random effect. Model random effect akan digunakan jika nilai prob. Cross section random > 0,05 dan sebaliknya jika prob. Cross section random $<0,05$ dan sebaliknya jika prob. cross section random < 0,05 maka fixed effect yang dipilih menjadi model regresi panelnya.

Adapun persamaan regresi yaitu sebagai berikut:

$\mathrm{Y}=\alpha+\beta 1 \mathrm{EPS}+\beta 2 \mathrm{DER}+\beta 3 \mathrm{ROE}+$ $\beta 4 \mathrm{CR}$

Keterangan :

$\mathrm{Y}=$ Variabel Price to Book Value

$\alpha=$ Konstanta

$\beta=$ Koefisien Regresi

EPS = Variabel Earning Per Share

DER = Variabel Debt To Equity Ratio

ROE = Variabel Return On Equity

$\mathrm{CR}=$ Variabel Current Ratio 


\section{Uji Hipotesis}

1. Uji Parsial (Uji T)

Pengujian secara parsial bertujuan untuk mengetahui pengaruh dan signifikansi dari masing-masing variabel independen dengan variabel dependen. Uji t yang digunakan dalam penelitian ini memilih tingkat keyakinan sebesar $95 \%$ dengan ketentuan (Santoso, 2006).

$\mathrm{H0}$ : jika nilai statistik hitung > statistik tabel $(0,05)$, maka $\mathrm{H} 0$ diterima

Ha : jika nilai statistik hitung < statistik tabel $(0,05)$, maka H0 ditolak

\section{Uji Koefisien Determinasi}

Koefisien determinasi digunakan untuk mengukur seberapa jauh kemampuan model dalam menerangkan variasi variabel dependen. Nilai koefisien determinasi antara nol atau satu. Nilai adjusted R2 yang lebih kecil mengartikan bahwa kemapuan variabelvariabel independen dalam menjelaskan variabel dependen sangat terbatas. Menurut Gujarati (2003) jika dalam uji empiris didapat nilai adjusted R2 negatif, maka nilai adjusted R2 dianggap bernilai nol. Dengan demikian, pada penelitian ini tidak menggunakan R2 namun menggunakan nilai adjusted $\mathrm{R} 2$ untuk mengevaluasi model regresinya.

\section{HASIL PENELITIAN DAN PEMBAHASAN}

\section{Hasil Penelitian}

1. Hasil Statistik Deskriptif

\begin{tabular}{|l|l|l|l|l|}
\hline & \multicolumn{1}{|c|}{ EPS } & \multicolumn{1}{c|}{ DER } & \multicolumn{1}{c|}{ ROE } & CR \\
\hline Mean & 113.9619 & 0.897917 & 6.664167 & 432.0071 \\
\hline Median & 20.87500 & 0.505000 & 8.345000 & 185.9150 \\
\hline Maximum & 4438.130 & 3.730000 & 84.60000 & 3266.160 \\
\hline Minimum & -485.2200 & 0.040000 & -55.92000 & 19.33000 \\
\hline Std. Dev & 658.9270 & 0.828472 & 22.79221 & 667.5254 \\
\hline
\end{tabular}

Beberapa penjelasan mengenai hasil analisis statistic deskriptif sebagai berikut:

a. Earning Per Share (EPS)

Hasil uji analisis statistik deskriptif menunjukkan EPS (X1) pada perusahaan sub sektor advertising printing media yang terdaftar di BEI 2014-2017 rata-rata (mean) 113.9619 dengan standar deviasi sebesar 658.9270. EPS tertinggi yaitu 4438.130 dimiliki oleh First Media Tbk dan yang terendah yaitu -485.2200 dimiliki oleh First Media Tbk juga.

b. Debt To Equity Ratio (DER)

Hasil uji analisis statistik deskriptif menunjukkan DER (X2) pada perusahaan sub sektor advertising printing media yang terdaftar di BEI 2014-2017 rata-rata (mean) 0.897917 dengan standar deviasi sebesar 0.828472. DER tertinggi yaitu 3.730000 dimiliki oleh MNC Sky Vision Tbk dan yang terendah yaitu 0.040 dimiliki oleh Star Pasific Tbk.

c. Return On Equity (ROE)

Hasil uji analisis statistik deskriptif menunjukkan ROE (X3) pada perusahaan sub sektor advertising printing media yang terdaftar di BEI 2014-2017 rata-rata (mean) 6.664167 dengan standar deviasi sebesar 22.79221. ROE 
tertinggi yaitu 84.60 dimiliki oleh First Media Tbk dan yang terendah yaitu -55.92 dimiliki oleh MNC Sky Vision Tbk.

\section{d. Current Ratio (CR)}

Hasil uji analisis statistik deskriptif menunjukkan CR (X4) pada perusahaan sub sektor advertising printing media yang terdaftar di BEI 2014-2017 rata-rata (mean) 432.0071 dengan standar deviasi sebesar 667.5254. CR tertinggi yaitu 3266.160 dimiliki oleh Star Pasific Tbk dan yang terendah yaitu 19.33 dimiliki oleh MNC Sky Vision Tbk.

\section{Hasil Asumsi Klasik}

a. Normalitas

Hasil Uji Normalitas

\begin{tabular}{|c|c|}
\hline Jarque-Bera & Probability \\
\hline 23.88608 & 0.000007 \\
\hline
\end{tabular}

Hasil uji normalitas pada tabel di atas nilai residual dalam model regresi tidak berdistribusi normal. Hal ini ditunjukkan pada nilai prob. J -B sebesar 0.000007, yang mana lebih kecil dari alpha 5\% $(0.000007<0,05)$. Untuk mengatasi masalah ini yaitu dengan menggunakan scatter plot pada excel dan menghilangkan data yang outlayer.

\begin{tabular}{|c|c|}
\hline Jarque-Bera & Probability \\
\hline 1.684187 & 0.430808 \\
\hline
\end{tabular}

menggunakan uji Jarque Bera. Berdasarkan hasil uji normalitas menggunakan uji Jarque Bera dilakukan perbaikan pada tabel di atasmenunjukkan bahwa residual persamaan regresi pada uji normalitas tersebut berdistribusi normal. Hal ini ditunjukkan pada nilai prob. J-B sebesar 0.430808 , yang mana lebih besar dari 5\% $(0.430808>0.05)$.

b. Autokorelasi

Hasil Uji Autokorelasi

\begin{tabular}{l|l} 
Durbin-Watsin stat & 1.490373 \\
\hline
\end{tabular}

Hasil uji korelasi terlihat pada tabel di atas bahwa nilai DurbinWatson stat adalah 1,490373, DL = $1, \mid 3619, \quad \mathrm{DU}=1,7206$. Dengan demikian dapat disimpulkan bahwa $1,3619<1.490373<1,7206$ yaitu tidak adanya kesimpulan.

Dengan ini akan diuji lagi menggunakan uji Breuch-Godfrey untuk memperjelas hasil analisis autokorelasi. Hasil uji B-G menunjukkan angka 0,0743 pada prob. Chi-Square, yang mana lebih dari $0,05 \quad(5 \%)$. Hasil ini menunjukkan hasil tidak adanya korelasi pada penelitian ini.

c. Heteroskedastisitas

Hasil Lij Heteroskedastisitas (White) \begin{tabular}{|l|l|l|l|}
\hline Obs*R-squared & 27.15050 & Prob. Chi-Scuare(14) & 0.0184 \\
\hline
\end{tabular}

Hasil Lji Heteroskedastisitas (Breusch-Godfrey) \begin{tabular}{|l|l|l|l|}
\hline Obs*R-squared & 16.12371 & Prob. Chir-Scuare(14) & 0.0029 \\
\hline
\end{tabular}

Dari hasil pemeriksaan terhadap gejala heteroskedastisitas dengan uji White pada tabel di atas menunjukkan masing-masing nilai prob. Chi-Square pada Obs*Rsquared $0,0184<0,05$. Maka uji heteroskedastisitas pada residual masing-masing regresi menunjukkan terjadi heteroskedastisitas. Hal ini juga terlihat dari nilai Prob. Chi-Square $0,0029<0,05$ pada uji B-G.

Hasil Uji Heteroskedastisitas(White) Perbaikan \begin{tabular}{|l|l|l|l|}
\hline Obs*R-squared & 21.26414 & Prob. Chi-Square(14) & 0.0951 \\
\hline
\end{tabular}

Untuk mengarasi masalah pada model panel dilakukan metode transformasi data dalam bentuk natural logarithm(Ln) dan kemudian 
diuji kembali dengan uji White sehingga mendapatkan hasil Prob. Chi-square 0,0952>0,05 yang menunjukkan hasil tidak adanya heteroskeastisitas.

d. Multikolinieritas

Tabel Hasil Uji Multikolinieritas

\begin{tabular}{|l|r|r|r|r|}
\hline & \multicolumn{1}{|l|}{ CR } & \multicolumn{1}{l|l|}{ DER } & \multicolumn{1}{l|}{ EPS } & \multicolumn{1}{l|}{ ROE } \\
\hline CR & 1.000000 & -0.313381 & 0.070306 & 0.3070077 \\
\hline DER & -0.313381 & 1.000000 & -0.805611 & -0686439 \\
\hline EPS & 0.070306 & -0.805611 & 1.000000 & 0.817400 \\
\hline ROE & 0.307077 & -0.686439 & 0.8177400 & 1.000000 \\
\hline
\end{tabular}

Uji multikolinieritas yang dilakukan menggunakan metode korelasi antar variable independen yaitu CR, DER, EPS dan ROE. Terlihat pada tabel di atas nilai korelasi antar variable independen CR, DER, EPS dan ROE <90\% atau 0,90, maka menunjukkan tidak adanya gejala multikolinieritas.

\section{Hasil Uji Regresi Data Panel}

Dalam pengujian analisis regresi terdapat tiga model yang bisa digunakan yaitu: ordinary least square atau common effect, fixed effect dan random effect. Pada penentuan model akan digunakan uji Chow (redundant fixed effect test) dan uji Hausman (correlated random effect test) yang dibantu dengan menggunakan software statistik Eviews.

Langkah awal dalam penentuan model adalah dengan meregresikan data dengan fixed effect, kemudian dilakukan dengan uji Chow dengan cara membandingkan nilai prob. Chi square dengan 0,05. Model common effect akan digunakan jika nilai prob. Chi square $>0,05$ dan sebaliknya jika nilai prob. Chi square >0,05 maka fixed effect yang dipilih. Langkah selanjutnya jika model yang digunakan adalah common effect maka penentuan model berhenti disini, dengan kata lain model yang lebih tepat digunakan adalah model common effect. Namun jika uji Chow menunjukkan bahwa fixed effect yang dipilih, maka akan dilanjutkan pengujian yang kedua (uji Hausman) yaitu dengan membandingkannya dengan model random effect.

Model random effect akan digunakan jika nilai prob. Cross section random $>0,05$ dan sebaliknya jika prob. Cross section random $<0,05$ dan sebaliknya jika prob.cross section random < 0,05 maka fixed effect yang dipilih menjadi model regresi panelnya.

Pada tabel di bawah ini secara ringkas disajikan keputusan mengenai penentuan model regresi panel yang digunakan dalam pengujian hipotesis dengan menggunakan Uji Hausman.

Hasil Uji Regresi Data Panel

\begin{tabular}{|l|r|r|r|}
\hline Test Summary & $\begin{array}{l}\text { Chi-Sq. } \\
\text { Statistic }\end{array}$ & Chi-Sq d.f & Prob. \\
\hline Cross-section random & 8.053071 & 4 & 0.0897 \\
\hline
\end{tabular}

Dari hasil regresi data panel pada tabel di atas terlihat nilai prob. Crosssectuon random sebesar 0,0897 $>0.05$, maka menunjukkan bahwa model random effect (GLS) yang digunakan dalam analisis regresi data panel.

4. Hasil Uji Parsial (Uji T)

Hasil Pengujian Pengaruh EPS, DER, ROE dan CR terhadap PBV

\begin{tabular}{|l|c|c|c|c|l|}
\hline Variable & Coefficient & Std. Error & t-Statistic & Prob. & Kesimpulan \\
\hline $\mathrm{C}$ & -0.902621 & 1.863681 & -0.484322 & 0.6337 & \\
\hline EPS & -0.236799 & 0.233468 & -1.014270 & 0.3232 & Tolak HI \\
\hline DER & -0.899551 & 0.328455 & -2.738731 & 0.0130 & Terima H2 \\
\hline ROE & 0.419779 & 0.251323 & 1.670275 & 0.1113 & Tolak H3 \\
\hline CR & 0.241178 & 0.323259 & 0.746081 & 0.4647 & Tolak H4 \\
\hline
\end{tabular}

Pada tabel di atas dapat diketahui hasil pengaruh EPS, DER, ROE dan CR terhadap PBV. Pengambilan keputusan berdasarkan nilai prob. yang di bandingkan dengan nilai alpha 5\% yang mana prob. $<0.05$, maka akan 
disimpulkan terdapat pengaruh yang signifikan. Untuk dapat menerima hipotesis alternatif selain terdapat pengaruh yang signifikan, arah pengaruhnya juga harus sesuai dengan hipotesis.

Pada variable Earning Per Share (EPS) terhadap Price to Book Value (PBV) menunjukkan pengaruh yang negatif tidak signifikan. Ditunjukkan dengan nilai prob. $0.3232>0.05$. Hal ini menunjukkan bahwa hipotesis pertama yang diujikan dalam penelitian ini yang menyatakan bahwa EPS berpengaruh negatif tidak signifikan.

Pada variable Debt To Equity Ratio (DER) terhadap Price to Book Value (PBV) menunjukkan pengaruh yang negatif signifikan. Ditunjukkan dengan nilai prob. $0.0130<0.05$. Hal ini menunjukkan bahwa hipotesis pertama yang diujikan dalam penelitian ini yang menyatakan bahwa DER berpengaruh negatif signifikan.

Pada variable Return On Equity (ROE) terhadap Price to Book Value (PBV) menunjukkan pengaruh yang positif tidak signifikan. Ditunjukkan dengan nilai prob. $0.1113>0.05$. Hal ini menunjukkan bahwa hipotesis pertama yang diujikan dalam penelitian ini yang menyatakan bahwa ROE berpengaruh positif tidak signifikan.

Pada variable Current Ratio (CR) terhadap Price to Book Value (PBV) menunjukkan pengaruh yang positif tidak signifikan. Ditunjukkan dengan nilai prob. $0.4647>0.05$. Hal ini menunjukkan bahwa hipotesis pertama yang diujikan dalam penelitian ini yang menyatakan bahwa $\mathrm{CR}$ berpengaruh positif tidak signifikan.
5. Hasil Uji Koefisien Determinasi Uji Koetisien Determinasi $\left(\mathbb{R}^{2}\right)$

\begin{tabular}{|l|r|l|r|}
\hline R-squared & 0.664526 & $\begin{array}{l}\text { Mean dependent } \\
\text { var }\end{array}$ & 1.044419 \\
\hline Adjusted R-squared & 0.593900 & S.D dependent var & 0.985756 \\
\hline S.E of regression & 0.628183 & $\begin{array}{l}\text { Akaike info } \\
\text { criterion }\end{array}$ & 2.091080 \\
\hline F-statistic & 9.409081 & Durbin-Watson stat & 0.755815 \\
\hline Prob(F-statistic) & 0.000228 & & \\
\hline
\end{tabular}

Dari tabel di atas bahwa variabel PBV mampu dijelaskan oleh variabel EPS, DER, ROE dan CR. Jika $R 2=$ 0.664526 artinya bahwa garis regresi menjelaskan $66,5 \%$ fakta, sedangkan sisanya sebesar $33,5 \%$ dijelaskan oleh variabel residual yaitu variabel di luar model yang tidak dimasukkan dalam penelitian ini.

\section{Pembahasan}

1. Pembuktian Hipotesis 1

Hipotesis 1 menduga bahwa Earning Per Share (EPS) berpengaruh positif terhadap Price to Book Value (PBV). Sedangkan hasil penelitian menunjukkan bahwa Earning Per Share (EPS) berpengaruh negatif tidaksignifikan terhadap Price to Book Value (PBV) sehingga hipotesis 1 tidak terdukung. Hal ini menunjukkan bahwa Price to Book Value (PBV) yang tinggi pada perusahaan advertising printing media yang terdaftar di BEI periode tahun 2014-2017 tidak dipengaruhi oleh besarnya nilai Earning Per Share (EPS).

Penelitian ini sesuai dengan penelitian karya Juwita (2017) yang menyatakan hal ini disebabkan karena harga saham saat ini merupakan cerminan dari kinerja sebelumnya, karena di periode yang sama kemungkinan harga itu tercerminnya nanti di periode berikutnya, sehingga hasilnya tidak signifikan. 
2. Pembuktian Hipotesis 2

Hipotesis 2 menduga bahwa Debt To Equity Ratio (DER) berpengaruh negatif signifikan terhadap Price to Book Value (PBV). Sedangkan hasil penelitian menunjukkan bahwa Debt To Equity Ratio (DER) berpengaruh negatif signifikan terhadap Price to Book Value (PBV) sehingga hipotesis 2 terdukung. Hal ini menunjukkan bahwa semakin tinggi nilai Price to Book Value (PBV) pada perusahaan advertising printing media yang terdaftar di BEI periode tahun 20142017 dipengaruhi oleh nilai Debt To Equity Ratio (DER) yang semakin rendah.

Hasil ini didukung oleh penelitian dari Donaldson (1961) yangmelakukan pengamatan terhadap perilaku struktur modal perusahaan di Amerika Serikat. Penelitian tersebut menunjukkan bahwa perusahaanperusahaan dengan tingkat profitabilitas yang tinggi cenderung rasio utangnya rendah.

\section{Pembuktian Hipotesis 3}

Hipotesis 3 menduga bahwa Return On Equity (ROE) berpengaruh positif terhadap Price to Book Value (PBV). Sedangkan hasil penelitian menunjukkan bahwa Return On Equity (ROE) berpengaruh positif tidak signifikan terhadap Price to Book Value (PBV) sehingga hipotesis 3 tidak terdukung. Hal ini menunjukkan bahwa Price to Book Value (PBV) yang tinggi pada perusahaan advertising printing media yang terdaftar di BEI periode tahun 2014-2017 tidak dipengaruhi oleh besarnya nilai Return On Equity (ROE).

Penelitian ini sejalan dengan hasil penelitian yang dilakukan Sasongko (2006) yang menyatakan bahwa tidak terdapat pengaruh positif Return On Equity (ROE) terhadap Price to Book Value (PBV). Hal ini berarti dari total modal yang ada tidak dapat mempengaruhi nilai perusahaan.

4. Pembuktian Hipotesis 4

Hipotesis 4 menduga bahwa Current Ratio (CR) berpengaruh positif terhadap Price to Book Value (PBV). Sedangkan hasil penelitian menunjukkan bahwa Current Ratio (CR) berpengaruh positif tidak signifikan terhadap Price to Book Value (PBV) sehingga hipotesis 4 tidak terdukung. Hal ini menunjukkan bahwa Price to Book Value (PBV) yang tinggi pada perusahaan advertising printing media yang terdaftar di BEI periode tahun 2014-2017 tidak dipengaruhi oleh besarnya nilai Current Ratio (CR).

Hasil penelitian ini sejalan dengan penelitian sebelumnya yang dilakukan Syarif (2014) yang menyatakan bahwa Current Ratio tidak berpengaruh signifikan terhadap nilai perusahaan. Dari pengukuran rasio, apabila rasio lancar rendah, dapat dikatakan bahwa perusahaan kurang modal untuk membayar utang dan apabila hasil pengukuran rasio tinggi, belum tentu kondisi perusahaan sedang baik (Kasmir, 2015).

\section{Hasil Koefisien Determinan (R2)}

Berdasarkan hasil uji R Square, dapat dilihat nilai koefisien determinasi (R Square) sebesar 0,665 atau 66,5\% dari variabel Price to Book Value (PBV) dapat dijelaskan oleh Earning Per Share (EPS), Debt To Equity Ratio (DER), Return On Equity (ROE) dan Current Ratio (CR). Sedangkan sisanya 33,5\% dijelaskan atau dipengaruhi oleh variabel-variabel (faktor atau rasio-rasio 
keuangan) lain yang tidak di teliti dalam penelitian ini.

\section{KESIMPULAN DAN SARAN}

\section{Kesimpulan}

1. Hipotesis 1 yang menyatakan bahwa Earning Per Share (EPS) berpengaruh postifit signifikan terhadap Price to Book Value (PBV) ditolak.

2. Hipotesis 2 yang menyatakan bahwa Debt To Equity Ratio (DER) berpengaruh postifit signifikan terhadap Price to Book Value (PBV) diterima.

3. Hipotesis 3 yang menyatakan bahwa Return On Equity (ROE) berpengaruh postifit signifikan terhadap Price to Book Value (PBV) ditolak.

4. Hipotesis 4 yang menyatakan bahwa Current Ratio (CR) berpengaruh postifit signifikan terhadap Price to Book Value (PBV) ditolak.

\section{Saran}

1. Untuk akademisi/ilmu pengetahuan, disarankan untuk menambah variabel atau tahun penelitian agar hasil penelitian lebih baik.

2. Untuk para investor, disarankan untuk meninjau rasio utang perusahaan untuk bahan pertimbangan keputusan investasi saham untuk meminimalisir risiko dan memaksimalkan keuntungan.

\section{DAFTAR PUSTAKA}

Brigham Eugene, F. dan J. Houston. (2004). Fundamentals of Financial Management Dasar-Dasar Manajemen Keuangan. Edisi 10. Buku 2. Jakarta: Salemba Empat.

Darmadji, T. Dan Fakhrudin. (2006). Pasar Modal di Indonesia Pendekatan Tanya Jawab. Jakarta: Salemba Empat.
Donaldson, C. (1961). Corporate Debt Capacity. Harvard University.

Ghozali, Imam. (2006). Aplikasi Analisis Multivariate Dengan Program SPSS. Cetakan Keempat. Semarang: Badan Penerbit Universitas Diponegoro.

Gujarati, Damodar. (2003). Ekonometri Dasar. Terjemahan: Sumarno Zain. Jakarta: Erlangga.

Hasania, Zuhria. (2016). Pengaruh Current Ratio, Ukuran Perusahaan, Struktur Modal Dan ROE Terhadap Nilai Perusahaan Farmasi Yang Terdaftar Di Bursa Efek Indonesia Periode 2011-2014. Jurnal Berkala Ilmiah Efisiensi. Vol. 16 No.3. Universitas Samratulangi.

Husnan, Suad. (2000). Manajemen Keuangan Teori dan Penerapan, Edisi Ketiga. Yogyakarta : UPP AMP YKPN.

Husnan, S dan E. Pudjiastuti. (2006). Dasar-Dasar Manajemen Keuangan. Edisi Kelima Cetakan Pertama. Yogyakarta: UPP STIM YKPN.

Indriyo, G. dan Sudita, Nyoman. (1997). Perilaku Keorganisasian. Edisi Pertama. Yogyakarta: BPFE.

Jogiyanto. (2010). Metodologi Penelitian Bisnis. Yogyakarta: BPFE.

Kasmir. (2015). Analisis Laporan Keuangan. Edisi Pertama Cetakan Kedelapan. Jakarta: Rajawali Persada.

Prasetia, Ta'dir Eko, dkk. (2014). Struktur Modal, Ukuran Perusahaan Dan Risiko Perusahaan Terhadap Nilai Perusahaan Otomotif Yang Terdaftar Di BEI. Jurnal EMBA. Vol. 2 No. 2. Universitas Samratulangi. 
Riyanto, Bambang. (2001). Dasar-Dasar Pembelanjaan Perusahaan. Edisi 4. Yogyakarta: BPFE.

Riyanto, Bambang. (2004). Dasar-Dasar Pembelanjaan Perusahaan. Edisi 4. Yogyakarta: BPFC.

Salvatore, Dominick. (2005). Ekonomi Manajerial Buku 2. Jakarta: Salemba Empat.

Santoso, Singgih. (2006). Menggunakan SPSS Untuk Statistik Non Parametrik. Jakarta: PT. Elex Media Komputindo.

Sugiyono. (2012). Memahami Penelitian Kualitatif. Bandung: Alfabeta.

Tandelilin, Eduardus. (2001). Analisis Investasi dan Manajemen Portofolio. Yogyakarta: BPFE.

Tjiptono, Fandy. (2006). Manajemen Jasa. Edisi Pertama. Yogyakarta: Andi.

Undang-Undang No.8 Tahun 1995 Tentang Pasar Modal.

Widarjono, Agus. (2013). Ekonometrika: Pengantar dan Aplikasinya. Jakarta: Ekonesia. 